committee's recent ex cathedra pronouncement on the pill, then there is surely enough evidence to publish.

The necessity of publishing the evidence is not the only lesson to be learnt from the recent series of bans. Even more alarming than the flouting of scientific conventions are the repercussions of the bans in other countries. It is true that the Wilson committee, for example, went out of its way to state that its advice applied only to Britain, but that is hardly enough. What happens at the moment is that a ban announced. in one country sparks off a panic in others, where the authorities, beeause of their ignorance of the new evidence, are wholly impotent either to quell public alarm or to know what action to take. In the case of cyclamates, the sudden and unexpected manner of the ban in the United States precipitated action by scientific committees in Sweden, Britain and other countries, which did no credit to anybody, and although Mr Finch, Secretary of the Department of Health, Education and Welfare, may indulge in the luxury of partly reversing the ban, it is far less easy for ministries in other countries to climb down. The effect abroad of the Scowen committee's pronouncement has been described (Nature, 224, 1141; 1969) and, had the reports of the Swann and Wilson committees been more sensational, these too could have created alarm elsewhere.

The anarchic situation of a ban in one country precipitating bans for the sake of bans elsewhere could be remedied by the simple expedient of exchanging new evidence, or now interpretations, between government authorities bcfore announcing any action. There is clearly a need for some international clearing house to be set up which could distribute information to interested national authorities in advance of any country announcing restrictive action. Although a certain amount of scientific information is exchanged through international agencies such as the World Health Organization, this machinery has certainly been too slow to act in the recent series of bans. In fact, remarkably little effort has been made by the authorities concerned to forewarn their colleagues elsewhere. The Food and Drug Administration in the United States at least provided the evidence on cyclamates to the British Ministry of Agriculture at the Ministry's request; the Scowen committee, however, has apparently informed nobody of the new evidence it possesses.

Prior exchange of this kind of evidence on an international basis would do much to soothe the present state of anarchy in which populations of one country are unnecessarily alarmed by a ban in another. Britain, Sweden and the United States have all been the victims of this confusion. Since these are the countries from which much of the new toxicological or epidemiological evidence originates, they would have everything to gain by initiating between themselves a club for exchanging such evidence prior to any recommendations being made. And there is no reason why the evidence should not be published either at the time of exchange or shortly afterwards.

\section{CERN ACCELERATOR Still in the Air}

ONCE again the CERN Council has failed to come to a firm decision on the fate of the $300 \mathrm{GeV}$ accelerator project. At the council meeting on. December 18 and 19 it was decided that the six countries which have announced their intention to join the project would hold a ministerial meeting in the very near future, and that the CERN Council would reassemble in March or earlier to reach a final verdict.

The Swiss Government has agreed to organize the ministerial meeting, in which the governments of Austria, Belgium, France, Italy, Switzerland and West Germany will be represented. The implication of the report issued by the CERN Council after the meeting is that the site for the accelerator, not the fate of the project itself, is the next question to be discussed.

The CERN Council has also approved the budget for the Meyrin (Geneva) site up to the end of 1973. This has been done in the context of a plan of development for the site up to 1975 . In $1970,244 \cdot 1$ million Swiss francs will be spent on the basic research programme, compared with Sw. fr. $235 \cdot 2$ million in 1969 , and Sw. fr. 81.9 million will be spent on the intersecting storage rings (which are scheduled for completion in 1971), compared with Sw. fr. 88.5 million in 1969. The full budgets up to 1973 are given in the table. They exclude the $300 \mathrm{GeV}$ accelerator project, but include the ISR and a small amount of additional income.

$\begin{array}{cc}\text { BUDGET FOR CERN (MEYRIN) UP TO } 1973 \\ \text { (in millions of Swiss francs) } \\ 1970 & 318 \cdot 1 \\ 1971 & 338.5 \\ 1972 & 351.8 \\ 1973 & 351.8\end{array}$

The CERN Council also agreed to a request from the European Southern Observatory for some form of collaboration between the two organizations, although no specific project was mentioned.

\section{PHARMACEUTICALS}

\section{Nimble with the Pill}

A FREQUENT happening in industrialists' nightmares must be that their product is about to be condemned. by a government committee and they have but a few days' grace to get an alternative on the market. The nightmare came true shortly before Christmas for manufacturers of the contraceptive pill when the Committee on Safety of Drugs issued its warning against formulations with a high dose of oestrogen.

It usually takes four to six weeks to prepare the packaging and labels for a new drug, but no more than four days after the committee's announcement, both G. D. Searle and Organon had launched new brands of low oestrogen pill. Although it is something of a coincidence that two companies should be apparently so well prepared, both deny having had. any prior knowledge of the committee's intentions. It seems, indeed, that each of the two companies accomplished a minor triumph of managerial skill in responding so quickly to the crisis.

Medical directors of pharmaceutical companies were 
summoned by telephone to a meeting with the committee on Wednesday, December 10, the secretary who issued the invitation refusing to give any indication of its purpose. It seems that at the meeting Professor E. F. Scowen, the chairman of the committee, was asked why he could not divulge the evidence on which the committee had acted. He is said to have replied that he regarded it as his duty to be prepared to give preliminary warnings when he considered them necessary, and that the committee could not wait until it had amassed full evidence because it would then be making a statement and not a preliminary warning.

Because of a leak that appeared in the press the following day, the committee decided to bring forward the date of its press conference, which was accordingly held on Thursday, December 11, before doctors had been warned.

Meanwhile the pharmaceutical companies had no time to lose in adjusting to the new situation. Organon, for example, was in particular straits because all three of its contraceptive pills were high oestrogen formulations. Fortunately, the company happened to have a low oestrogen formulation ready on its shelves, production of which was started on Friday, December 12. The trade name for the new brand, Minilyn, had already been registered, and the approval of both the Committee on Safety of Drugs and the Family Planning Association was obtained on the Friday. The packaging problem was met by an unusual improvisation; Organon located a firm in Hertfordshire that manufactures wage packets, a large quantity of which were bought up and dispatched to the company's production plant in Scotland. Labels were hastily printed and the first deliveries of Minilyn were made on Monday, December 15, a bare five days after the committee had uttered its fiat.

Similar feats of improvisation were accomplished by G. D. Searle and Co., whose Ovulen-50 was also launched on the Monday following the announcement. Searle also happened to have a low dose oestrogen formulation in stock which had been prepared in response to requests from doctors in the Far East. The product was launched in the packages used for another pill in the Searle range with overprinted labels. A spokesman at the company said they had amazed even themselves by the speed at which Ovulen-50 was seen onto the market.

\section{LABORATORIES}

\section{Physics by the Thames}

THE latest annual report of the National Physieal Laboratory at Teddington (HMSO, £l 8s) makes solid reading. Clearly the laboratory has now adapted to its division into three groups devoted to measurement, materials and engineering sciences, with control firmly in the hands of the Ministry of Technology and the Royal Society playing an advisory part. The old NPL steering committee and the visiting board which used to oversee the activities of the laboratory have now disappeared. There is now a six-man advisory board which first met in June last year. The function of the advisory board is to inspect the laboratory at least three times a year and to report annually to the Ministry of 'Technology. With the ministry's unabashed devotion to the industrial application of science, it might now be the time to change the name to the National Technical Laboratory, but that would be to ignore seventy years of history.

Part of the difficulty in bringing the achievements of the NPL into focus is that its objectives are so diffuse. The present annual report still quotes the 1900 definition-"to bring scientific knowledge to bear practically upon our everyday industrial and commercial life, to break down the barrier between theory and practice, to effect a union between science and commerce". What people should be asking is whether this is sufficient guidance for those spending the $£ 5 \cdot 1$ million which was the direct expenditure of the NPL in 1968-69. On the admission of the director, Dr J. V. Dunworth, the NPL has never been concerned with large scale projects, and has not played a large part in the developing technologies of recent years, which is why its research programme has an old-fashioned look about it. Changes show up best in the engineering sciences group, which, as well as the traditional work on ships, is developing a healthy interest in computers. At present, the Division of Computer Science is concentrating on ways of making printed matter and speech accessible to computers and on the development of a data communication network.

What the NPL is hoping is that its putative com. munications network will be chosen by the Post Office as the design for a national data communications system. Whether this happens depends on technical and market surveys being carried out for the Post Office, but it seems probable that the NPL scheme is likely to be adopted only if the surveys reveal a booming market for data communications, chiefly because the NPL proposal is for a large capacity network with computers to control the switching of messages through the system. To test the principle, a small scale network is nearing completion to serve the needs of the laboratory and to represent a small branch of a national network. The laboratory's computers are to be connected to various input and output devices such as teleprinters, line printers, display units and data collection equipment through a smajl intermediate computer which will be the switching unit.

In the main, the Engineering Sciences Division seems concerned to do work which is not possible for industry because of the expense or the facilities required. Otherwise the NPL looks like a rather grandiose advisory centre for government and industry. The 269 pages of the annual report give the impression that the NPL is doing a lot of good physics which is just waiting to be pounced on by commercial interests, but it would be more convineing if the industrial connexions were clearer.

\section{ENVIRONMENT \\ Spreading the Word}

THE poet Ted Hughes, the Sovietologist Daniel Weissbort and the author David Ross are editing a magazine called Your Environment which was published for the first time last month. "Our overriding ambition," proclaims the introductory editorial, "is to be instrumental in the provision of practical solutions," and the magazine's intention is to offer informed articles on conservation, pollution and natural resources rather than to join the fashionable panic. Your Environment will appear quarterly (annual subscription 30 s from 10 Roderick Road, London NW3). 